Editorial Office: Rectorate Building, Floor V, Jl. Prof. Dr. Sumantri Brojonegoro No. 1 Bandar Lampung, 35145, INDONESIA

Mobile: +62 813-6741-6145, Phone/Fax +62 721702767

Email: jassp@kpa.unila.ac.id, Website: https://jassp.lppm.unila.ac.id

\title{
Micro Small-Level Enterprises (MSES) and Cooperatives in Presidential Regulation Number 12 of 2021
}

\author{
Adam Khafi Ferdinand ${ }^{1}$ \& Rinaldy Amrullah ${ }^{2}$ \\ ${ }^{1}$ Anti-Corruption and Human Right Research Center (Puskamsikham), Faculty of Law, University of Lampung, \\ Lampung, Indonesia, Email: adamkferdinand12@gmail.com \\ ${ }^{2}$ Anti-Corruption and Human Right Research Center (Puskamsikham), Faculty of Law, University of Lampung, \\ Lampung, Indonesia, Email: rinaldy.amrullah@ fh.unila.ac.id \\ Received: March 31, 2021 Accepted: September 23, 2021 Online Published: October 27, 2021
}

\begin{abstract}
Presidential Regulation Number 12 of 2021 concerning amendment the Presidential Regulation Number 16 of 2018 (Presidential Regulation 12/2021) was the government efforts for micro small-level enterprises (MSEs) and cooperatives to be involved in the public procurement of goods and services. However, it still needs to be anticipated because there are always irregularities that usually occur, namely corruption. This research aims to determine how the amendment of the public procurement regulation in the Presidential Regulation 12/2021 especially for MSEs and cooperatives, and also how to assess the Presidential Regulation 12/2021 can reduce the potential for corruption in the process of public procurement. This research uses a normative method with a comparative approach and a statutory approach. The results of this research indicate the Presidential Regulation 12/2021 are the elimination of medium-level enterprises, the government's obligation to allocate a minimum budget of $40 \%$, and also increase the budget ceiling for MSEs and cooperatives up to IDR 15 billion. EProcurement for MSEs and cooperatives still has the potential for corruption, but with the new policy in the form of competency certification, and if there is an increase in regulations from the National Procurement Board (LKPP) in terms of provider qualifications, procurement can produce quality and efficient products.
\end{abstract}

Keywords: Potential Corruption, Government's Procurement Goods and Services, Presidential Regulation 12/2021, Small-Level Enterprises (MSEs), Cooperatives

\section{Introduction}

The seriousness of the Indonesian government in improving the economy is evident in Law Number 11 of 2021 concerning Job Creation (Job Creation Law) or also known as the Omnibus Law. At the end of 2020, the House of Representatives (DPR) and the Government of Indonesia jointly approve it. The Job Creation Law is expected to be useful for the purpose of structural reform and accelerating economic transformation in Indonesia (BPMI Setpres. 2020, October 9). Apart from all polemic and political interventions which were so strong and the disapproval of some citizens towards Job Creation Law, there are positive sides that can be seen, especially in the sector of Micro Small-Level Enterprises (MSEs) and Cooperatives. One of the visions in the preamble to the Job Creation Law has shown the governments are eager to encourage convenience and create protection and also economic empowerment, especially in the sector of MSEs and Cooperatives. In addition, another intention is that the emergence of the Job Creation Law is also expected to suppress the creation of new MSEs and able to open up more job opportunities as possible.

In the Job Creation Law specifically on Chapter V concerning the Ease, Protection and Empowerment of Cooperatives, Micro Small Medium-Level Enterprises (MSMEs), it changes regulates, deletions, and stipulations of new rules relating to MSMEs in Law Number 20 of 2008 concerning Micro, Small and Medium Enterprises (Law Number 20/2008) and amendments of the Cooperatives in Law Number 25 of 1992 concerning Cooperatives (Law Number 25/1992).

The changes of the Job Creation Law have implications for the activities of government procurement goods and services by MSEs and Cooperatives which were previously regulated in Presidential Regulation Number 16 of 2018. The amendments of Job Creation Law are finally to emergence a new policy namely Presidential Regulation Number 12 of 2021 concerning the amendments of Presidential Regulation Number 16 of 2018 
concerning governments Procurement Goods and Services (Presidential Regulation 12/2021). Apart from those related to MSEs and Cooperatives, there are other several provisions amended in the Presidential Regulation $12 / 2021$, it is relating about domestic products, human resources, procurement institution, procurement personnel, construction services, fostering providers, and also about e-marketplace in governments procurement goods and services. The amended provisions fall within the scope of changes to the cluster of convenience and protection of MSEs as well as the ease of doing business in the Job Creation Law.

The influence of the Job Creation Law can be seen from the change in the objectives of government's procurement of goods and services in the Presidential Regulation 12/2021, which in Article 4 Letter C states that these changes encourage an increase in the participation of MSEs and Cooperatives and aim to realize economic equity and expand business opportunities. Another change of concern is also found in Article 65 of the Presidential Regulation 12/2021, the Ministries/Institutions/Regional Governments (K/L/PD) were obligated to use domestic MSE and Cooperative products by allocating at least $40 \%$ of the value of the expenditure budget. Then, the budget ceiling value earmarked for MSEs and Cooperatives was also increased to 6 (six) times, from originally only IDR 2,5 Billion now to IDR 15 Billion. That change is certainly becoming an opportunity for providers/entrepreneurs in the MSEs and Cooperatives, where they are encouraged to have greater budget absorption than before. Given that based on data from http://inaproc.id/ukm as of July 30, 2020, from the total value of packages reserved for MSEs of IDR 307 Trillion, but the realization of the packages for MSEs is only IDR 56 Trillion or 18,2\% from the total value of the package backup (Ministry of Cooperatives and SMEs RI, 2020).

Talking about the government's procurement of goods and services, the purpose of these activities does have a noble purpose where the activities of the government's procurement of goods and services is a tool to move the wheels of the economy for the welfare of the lives of the Indonesian people. This is also because the government's procurement of goods and services is a public sector that is closely related to the use of the state budget, both the State Revenues and Expenditures Budget (APBN) or the Regional Revenues and Expenditures Budget (ABPD) (Azijah Dewi Noor. 2019). Since it was first regulated in Presidential Decree Number 80 of 2003, the government's procurement of goods and services has undergone several changes until currently in effect, namely Presidential Regulation Number 16 of 2018 concerning the Government's procurement of goods and services (Presidential Regulation 16/2018) and Presidential Regulation Number 12 of 2021 concerning Amendments to Presidential Regulation Number 16 of 2018 concerning the Government's procurement of goods and services (Presidential Regulation 12/2021).

Policies have indeed been implemented several times, advances in information technology and the times demanded a change. Policy changes in the government's procurement of goods and services regulations are also encouraged because there are still many legal loopholes and irregularities in the goods and services procurement process. Irregularities are closely related to the government's procurement of goods and services activities and are still a polemic that continues to be resolved, such as the issue of corruption. Development that wants to be reached by a state would be hampered by corruption because corruption is very detrimental to the state's budget and economy. Therefore, corruption must be eradicated to achieve the development goals and create a just and prosperous society (Sabrina Dyah Nayabarani. 2017).

Studies on irregularities in the form of corruption in the government procurement sector have been scattered everywhere and have been carried out by researchers and legal observers in Indonesia. Bribery, gratification, conspiracy, mark-up, kickback in the government's procurement of goods and services can always occur at every stage of the procurement method used, even in the government's procurement of goods and services even with a small nominal, such as MSMEs and Cooperatives. The increase in the amount of the budget ceiling and the allocation obligation of $40 \%$ for MSEs and cooperatives in the government's procurement of goods and services can indeed be a positive value in the ease of doing business (EoDB). However, it is also necessary to be alert to any negative indications in the form of legal loopholes that can be exploited by people who are immoral and greedy towards the use of the state budget that is not in accordance with its allocation. Therefore in this paper, I want to review how the amendment of the government's procurement of goods and services, especially for MSEs and cooperatives in the Presidential Regulation 12/2021, and also I want to review how to assess the Presidential Regulation 12/2021 can reduce the potential for corruption in the process of the government's procurement of goods and services, especially for MSEs and cooperatives. 


\section{Methods}

This research uses the normative legal writing method, namely the method using the literature method consisting of secondary legal materials and laws and regulations relating to these legal issues, then supported by data and other secondary materials related to the problems under study. The object of study of this research is Presidential Regulation Number 12 of 2021 concerning Amendments to Presidential Regulation Number 16 of 2018 concerning Government's Procurement of Goods and Services (Presidential Regulation 12/2021). Meanwhile, the approach used is a comparative approach and a statutory approach.

\section{Discussion}

3.1 Amendment of The government's Procurement of Goods and Services Regulation especially for MSEs and Cooperatives in Presidential Regulation Number 12 of 2021

On February 2, 2021, the government issued Presidential Regulation Number 12 of 2021 concerning Amendments of Presidential Regulation Number 16 of 2018 concerning the government's Procurement Goods and Services (Presidential Regulation 12/2021). This change is also inseparable from the impact of the Corona Virus Disease (Covid-19) Pandemic, Indonesia itself has implemented a Large-Scale Social Restriction (PSBB) policy which caused the Indonesian economy to sluggish (Muzakir Haitami, \& Alya Rengganis. 2021). In the socialization, the Head of the National Procurement Board (LKPP), Dr. Ir. Roni Dwi Susanto., M.Si said that the public procurements are one of the driving forces of the economy which provides possible job opportunities, ease the citizen specifically for MSEs to open up a new business and also support the prevent and eradicate the corruption (LKPP. 2021c, February 26).

Regarding the policy amendment of Presidential Regulation 12/2021 which changes several provisions are related to the government procurement of goods and services for MSEs and Cooperatives in Presidential Regulation 16/2018 can be seen in this table below:

Table 1. Comparing the Policy of The Government's Procurement Goods and Services that related for MSEs and Cooperatives in Presidential Regulation 12/2021 and Presidential Regulation 16/2018 (LKPP, 2021).

Num. EARLY ARTICLE

(Presidential Regulation 16/2018)

1. Article 1 Point 47:

Medium Enterprises are productive economic enterprises that are independent, carried out by individuals or business entities that are not subsidiaries or branches of companies that are owned, controlled, or are part of, either directly or indirectly, with Small or Large Businesses with total net assets or annual sales proceeds as regulated in the Law on Micro, Small and Medium Enterprises.

2. Article 4 Letter C:

. increasing the participation of Micro, Small and Medium Enterprises;

3. $\quad$ Article 19 Letter C:

maximize the use of green industrial products

4. Article 65:

Small business consists of Micro and Small

Enterprises.

In the procurement of goods and services, PA / KPA expands the role of small businesses.

The packaging is carried out by determining as many packages as possible for small businesses without neglecting the principles of efficiency, fair business competition, system unity, and quality of technical capabilities..
ARTICLE AMENDMENT

(Presidential Regulation 12/2021)

Article 1 Point 47:

Deleted

Article 4 Letter C:

increasing the participation of Micro, Small

and Cooperatives;

Article 19 Letter C and D:

products of micro small-enterprises and cooperatives from domestic production; dan environmentally friendly product.

Article 65:

Small business consists of Micro and Small Enterprises.

Ministries / Institutions / Regional government are required to use products of micro-small and cooperatives products from domestic production.

Ministries / Institutions / Regional Governments as referred to in paragraph (2) are required to allocate at least $40 \%$ (forty 


\begin{abstract}
The value of the package for procurement of goods / construction work / other services is not more than IDR 2,500,000,000.00 (two billion five hundred million rupiahs), reserved and allocated for small businesses, except for work packages that require technical capabilities that cannot be fulfilled by small business. The National Procurement Board (LKPP) and Ministries / Institutions / Regional Governments expand the participation of small businesses by including goods and services produced by small businesses in the electronic catalog.
\end{abstract}

percent) of the budget value for goods and services expenditures of the Ministries / Institutions / Regional Governments. The package for procurement of goods / construction work / other services with a ceiling value of up to Rp. 15,000,000,000.00 (fifteen billion rupiahs) is intended for small businesses and / or cooperatives.

The budget ceiling value for procurement as referred to in paragraph (4) is exempted for work packages that require technical capabilities that cannot be fulfilled by small businesses and cooperatives.

The ministry which organizes government affairs in the field of cooperatives and small businesses and the Regional Government expands the participation of small businesses and cooperatives by including goods and services produced by small businesses and cooperatives in the electronic catalog. Providers of non-small businesses or cooperatives carrying out work collaborating with small businesses and / or cooperatives in the form of partnerships, subcontracts, or other forms of cooperation if some small businesses or cooperatives have capabilities in the relevant field.

Cooperation with small business and / or cooperatives as referred to in paragraph (7) shall be included in the Bidding Document.

Based on the table above, it can be seen that there are several provisions amended in the Presidential Regulation 12/2021. The point of concern is in Article 1 Point 47 and Article 4 Letter C which is Medium-Level Enterprises has been deleted. The elimination of medium-level enterprises in the Presidential Regulation 12/2021 is a provision amended due to the emergence of Job Creation Law as regulated in Article 97, namely (Law Number 11/2020):

"The Central Government and Regional Government are required to allocate at least 40\% (forty percent) of products / services of MSEs and Cooperatives from domestic production in the public procurement by the Central Government and Regional Government following with the provisions of laws and regulations."

From that provision, the government does not mention the existence of medium-level enterprises, but rather the focus of the government is to prioritize the interests of MSEs and Cooperatives, so that causes changes the medium-level enterprises in Presidential Regulation 12/2021.

It should be remembered, that this elimination does not merely cause medium-level enterprises activities to no longer to exist in Indonesia. Medium-level enterprises are still regulated in Law Number 20 of 2008 concerning Micro, Small and Medium Enterprises (Law 20/2008) and Government Regulation Number 7 of 2021 concerning Ease, Protection and Empowerment of Cooperatives and Micro, Small and Medium Enterprises (PP 7/2021). In addition, if we pay attention from the start, the general provisions of Article 1 of the Presidential Regulation 16/2018 also did not mention the definition of Large Business. In this case, the same treatment also occurs for medium-level enterprises in the Presidential Regulation 12/2021. The elimination of medium-level enterprises in Presidential Regulation 12/2021 further explains that medium-level enterprises are being treated increasingly firmly as non-small businesses in the government procurement of goods and services.

Other points that are also not less interesting, namely the changes in the provisions of Article 65 Presidential Regulation 12/2021. As explained above, the government through the Job Creation Law wants to encourage the 
MSEs and Cooperative sector by requiring the central government and regional governments to allocate a budget for goods and services to MSEs and cooperatives by $40 \%$. Therefore, those wishes have been regulated in Article 65 paragraph (3) in the Presidential Regulation 12/2021. In addition, Article 65 paragraph (2) also stipulates that Ministries/Institutions/Regional Governments (M/I/RG) is obliged to use domestic products, so it can be concluded that the Ministries/Institutions/Regional Governments (M/I/RG) budget with a value of at least $40 \%$ must be allocated to domestic production from MSEs and Cooperatives. The mandatory use of domestic products itself is also meant for products that have a Domestic Component Level (TKDN) of at least 40\%, as referred to in Article 66.

Furthermore, from the provisions of Article 65 paragraph (4) in the Presidential Regulation 12/2021, the government also increases the limit on the amount (or budget ceiling value) for the procurement of goods / construction works / other services from MSEs and Cooperatives from IDR 2,500,000,000 to IDR $15,000,000,000$. The change in these limits is also due to adjustments from PP 7/2021 which determine the limit of annual sales proceeds for MSEs of a maximum of IDR 15 billion. However, the budget limit / ceiling can be exempted by paragraph (5) if the work package that demands technical capabilities cannot be fulfilled by MSEs and Cooperatives (Makarim, \& Taira S. 2021).

The amended provisions in the Presidential Regulation 12/2021 do seem to be a very big opportunity for MSEs and Cooperatives to participate in the government procurement of goods and services. Especially with the obligation to allocate $40 \%$ with the mandatory use of domestic products. The application of DCL for products that are included in the E-catalog will indeed make it easier for MSEs and Cooperatives to market their products in the E-catalog. The entry of products from MSEs and Cooperatives into the E-catalog will increase turnover and the development of MSEs and Cooperatives, in this case, it seems that the government also indirectly has the intention of encouraging the slogan of 'Love Indonesian Products'. However, not all policies can be seen from the positive side, we also need to look at the legal loopholes and weaknesses of any existing rules and policies. The budget limit/ceiling rule that was increased 6 (six) times to IDR 15 billion can indeed be an opportunity to open up new MSEs, but it can also create random MSEs offering fewer quality goods/services. MSEs and Cooperatives like this can be called 'Palu Gada' (what do you want, I exist) (Iqbal, M. (2020).

In The National Procurement Board Regulation Number 9 of 2018 concerning Guidelines for the Implementation of the Procurement of Goods and Services through Providers (PerLKPP 9/2018) there are several provisions including qualification requirements for providers, one of which is the Provider's Technical Qualification Requirements as set out in the PerLKPP 9/2018 Appendix Number II point 3.4.2, where both the requirements for providers of goods or services can be added to the provisions regarding the highest work value in the last 10 (ten) years also intended for Small and Non-Small businesses at least equal to $50 \%$ (fifty percent) of the total value of the Owner Estimate / Budget Ceiling. So that not only Non-Small businesses but small businesses such as MSEs also qualify, and qualification does not only apply to services but can also be applied to providers of goods.

Furthermore, regarding the Financial Capability Qualification Requirements as stipulated in the PerLKPP 9/2018 Appendix Number II point 3.4.3, where the provision regulates financial capacity in the form of Remaining Actual Potential (RAP) accompanied by financial reports for providers who are or will be working on work packages. However, the RAP is exempted for MSEs. In response to this, in the opinion of the author, the National Procurement Board (LKPP) can also change several provisions in which both Small (MSEs) and Non-Small providers can be asked for RAP and financial reports as qualification requirements. There is nothing wrong if RAP and financial reports are the qualification requirements to determine quality goods and service providers. This is because the provisions for government procurement of goods and services have changed in Presidential Regulation 12/2020, so that the National Procurement Board (LKPP) can also make adjustments to related regulations.

Adjustments in the form of limitations with certain qualification requirements on the selection of providers of goods and services including for MSEs and Cooperatives are intended so that procurement is not only concerned with low prices but also can produce quality and efficient goods and services. In this case, it is the responsibility of the evaluation of the Electoral Working Group (EWG) and the Commitment Maker Office (CMO) in each M/I/RG. However, even though there will be a limit made by the National Procurement Board (LKPP), this limit is also expected so as not to reduce the interest of new business actors but still be able to maintain the good intentions of the government to provide wider space for MSEs and Cooperatives so that they are not used by 
unscrupulous individuals which just want to have a project, and minimize the emergence of various kinds of other irregularities and even the potential for corruption, collusion, and nepotism.

\subsection{Assessing The Presidential Regulation 12/2021 Can Reduce The Potential For Corruption In The Process} Of The Government's Procurement Of Goods And Services, Especially For MSEs And Cooperatives

Government procurement of goods and services is one of the tools to move the wheels of the economy to improve the national economy to create people's welfare and improve the quality of human resources (Rendra Alfonso Sitorus, Syafruddin Kalo, Mahmul Siregar, \& M. Ekaputra. 2019). As we know that the procurement of goods and services is very important in the activities of government organizations. Each M/I/RG unit requires procurement and this is repeated throughout the fiscal year (Kementerian Keuangan. 2014). Therefore, all systems and policies need to facilitate their implementation. With a good system and good policies, it can also minimize various kinds of irregularities that occur in the government procurement of goods and services including acts of corruption, collusion, and nepotism.

In the process, there is the concept of mapping the goods and services to the needs of organizations that can refer to the Kraljic Matrix or Model Kraljic, where the goods and services are categorized based on the value of spending and the impact or risk to the organization. The categorization of goods and services is divided into 4 (four) quadrants (Peter Kraljic, 1983) namely:

a. The non-critical / routine quadrant, goods or services that have a low expenditure value (such as daily operational needs), and have a small impact / risk for the organization. Generally, these goods or services can also be provided by many service providers or business actors.

b. The leverage quadrant, is a category of goods or services that have a large expenditure value, but the impact /risk for the organization is relatively small. Generally, these goods or services can be provided by many service providers or business actors.

c. The bottleneck quadrant, namely goods or services that have a low expenditure value, but have a large impact / risk for the organization. These goods or services are generally provided by specific/specific goods and services providers or business actors.

d. The critical / strategic quadrant, is goods or services needed by the organization that has a high expenditure value and has a large impact / risk for the organization. These goods or services are generally provided by goods and services providers or business actors who have the main business in their respective fields.

Of the four quadrants, it is possible for the government procurement of goods and services in the $M / \mathrm{I} / \mathrm{RG}$ organization to the MSMe and Cooperatives sectors to be in the non-critical / routine quadrant. The procurement process can also be carried out electronically (e-procurement) with the direct electronic procurement method, namely the E-Purcashing method through E-Catalogs or Online Stores which are currently regulated in Article 1 Number 35 and Article 1 Point 54 in the Presidential Regulation 12/2021.

Inside the book from the Ministry of Cooperatives and SMEs of the Republic of Indonesia entitled BANGGA UMKM (Guidebook for the Procurement of Government Goods and Services for Cooperatives and MSMEs), the involvement of MSMEs and Cooperatives in the government procurement of goods and services can be done through Direct Expenditure Procurement (BELA Pengadaan) for procurement up to IDR 50,000,000 (fifty million rupiah), Electronic Direct Procurement for procurement of IDR 50,000,000 (fifty million rupiah) up to IDR 200,000,000 hundred million rupiah), or through E-Catalog for E-Purchasing purchases. (Kementerian Koperasi dan UKM, n.d., p. 4). The difference between Procurement Defense and E-Catalog, where Bela Procurement for procurement is up to IDR 50,000,000 (fifty million rupiah), while e-purchasing through ECatalog is not limited in value.

The Direct Expenditure Procurement (BELA Pengadaan) Program is an implementation of the program as regulated in the Circular Letter of the Head of the National Procurement Board Number 18 of 2020 concerning Electronic Direct Procurement for Micro and Small Businesses (SE LKPP 18/2020) and is further regulated in the Decree of the Head of the National Procurement Board Number 200 of 2020 concerning Procurement Defense Program (SK LKPP 200/2020). The Direct Expenditure Procurement (BELA Pengadaan) can be accessed through https://belapengadaan.lkpp.go.id/ where it is connected to registered aggregators such as Gojek, Grab, Shopee, Bhinneka, Blibli, Bukalapak, and other e-commerce (Kementerian Koperasi dan UKM, n.d., p. 12). In addition, there is an official website belonging to the National Procurement Board (LKPP), namely http://inaproc.id/ which functions as a portal or gate for electronic information systems related to information on the government procurement of goods and services nationally which provides access and links to 
all procurement services electronically, catalogs. goods for e-purchasing, and is included in the blacklist of providers of goods and services (LKPP, 2012).

It should be noted that E-procurement is divided into 2 (two), namely E-tendering and E-purchasing. ETendering is the process of procuring goods and services that are followed by goods and services providers electronically through a one-time offer, while E-Purchasing is the process of procuring goods and services through an electronic catalog. The E-Tendering process is the same as the procurement pattern that has been carried out manually, the only difference is that all stages are carried out electronically, while E-Purchasing uses a completely different method. Users of goods and services only need to choose the goods and services they want through an open and transparent electronic catalog (Liziad Aditya Soetanto, et al. 2015). In this case, the procurement of goods and services is carried out in the Electronic Procurement System (SPSE) in each related agency by the Electronic Procurement Service (LPSE). Business actors (including MSEs and Cooperatives) must also input qualification and profile data in the Provider Performance Information System (SIKaP). The process of procuring electronic goods and services (e-procurement) is indeed a more advanced procurement process than conventional procurement processes and has the objective of making the government procurement of goods and services more effective, efficient, open and competitive, transparent, fair or non-discriminatory, and accountable (Haryati, D.,et al. 2011).

To procure goods and services electronically, personnel are appointed to carry out the task of procuring government goods and services, including a Procurement Officer, a Commitment Making Officer (CMO), and an Electoral Working Group (EWG). However, in Article 13 Paragraph (1) Letters a and b in the Presidential Regulation 12/2021, at this time the Electoral Working Group (EWG) no longer has the authority to carry out the selection of providers using of E-Purcashing and Direct Procurement. The implementation of direct procurement and E-Purcashing can be carried out by the Procurement Officials for a maximum value of IDR 200,000,000,- (two hundred million rupiah) and Commitment Making Officer (CMO) for a value of at least over IDR 200,000,000,- (two hundred million rupiah), as referred to in Article 12 paragraph (1) letter d and Article 11 paragraph (1) letter $\mathrm{h}$.

The government procurement of goods and services must be carried out credibly through sound, independent (impartial) arrangements and ensuring economic and social interactions between parties. Credible procurement also means preventing unfair business competition and contains elements of preventing corruption, collusion, and corruption between procurement actors and providers (Beridiansyah. 2017). Procurement of goods and services through electronic systems is expected to provide a budget. Several procurement officials stated that it is more than using an electronic catalog because apart from being easy to procure, there is also a legal umbrella to protect oneself from legal action in the future. Apart from procurement, the procurement of goods and services through e-buying can also minimize acts of corruption (Lestyowati, J. 2018). Another advantage is community supervision so that it is hoped that in the future it can reduce fraud (Adrian Sutedi. 2012). However, the optimal goal of establishing an electronic goods and services procurement system is not as easy as we think. As we know, the procurement of electronic goods and services has been implemented in Indonesia for a long time, but until now there are still various kinds of irregularities in terms of principles, ethics, maladministration and even acts of corruption, collusion, and nepotism.

According to the Indonesian Dictionary (KBBI), corruption is defined as an act of using power for one's interests (such as embezzling money or accepting bribes) (Pusat Bahasa Departemen Pendidikan Nasional. 2008). In the Black's Law Dictionary, Corruption is "An act committed with the intention of giving an advantage that is not by the official obligations and rights of other parties, wrongly using his position or character to get an advantage for himself or someone. other, along with the obligations and rights of other parties”( Henry Campbell Black, M. A. 1968).

Based on data from the Corruption Eradication Commission (KPK), every year corruption in the procurement of government goods and services always actively participates in the KPK's statistical data. The below is statistical data on corruption based on the types of cases from the KPK (KPK. 2021): 


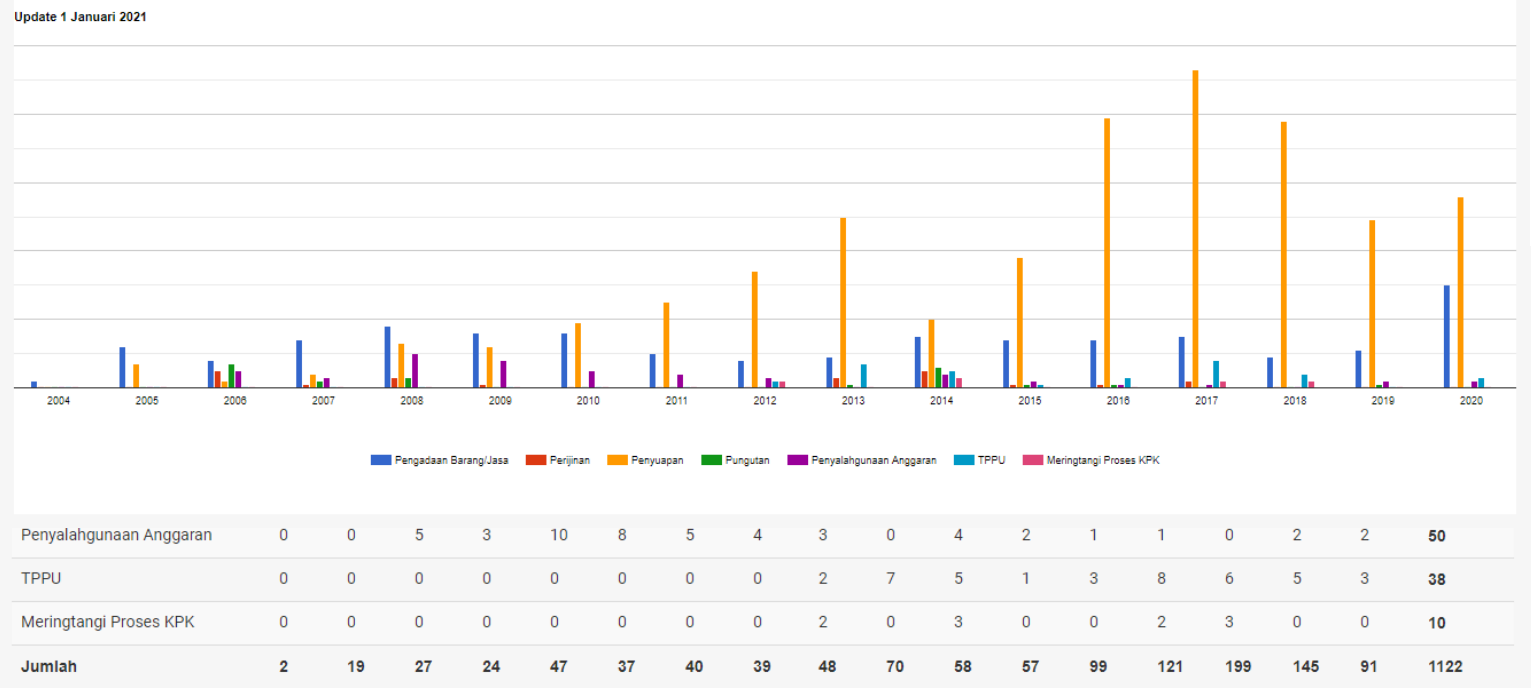

Based on the statistical data above, corruption in the government procurement of goods and services is still the prima donna, occupying the top rank with the second-highest number after bribery. Even in 2020, corruption in the goods and services procurement sector has broken the most records compared to the previous year with a total of 30 (thirty) cases. This is very worrying considering that 2020 is the year of the Covid-19 outbreak and is even still ongoing today. When other people are being hit by disaster, some greedy people are looking for opportunities by committing corruption amid a pandemic. Therefore, various kinds of updating systems and policies in the procurement of goods and services sometimes still do not go straight with human resources.

One example is the alleged corruption case of the procurement of agricultural machinery (Alsintan) in the form of two-wheeled tractors, four-wheeled tractors, rice transplants, seeding trays, and water pumps at the 2015 Ministry of Agriculture which is currently still undergoing the process examination of the Team of Investigators at the Junior Attorney General for Special Crimes at the Attorney General's Office of the Republic of Indonesia (AGO). The AGO examined 3 (three) witnesses, namely Dwi Satrianto as the Head of Sub-Directorate for LKPP System Development Catalog Management for Fiscal Year 2015 as the 2015 LKPP E-Catalog Development Team, Sigit Apriyanto as the 2014 LKPP E-Catalog Working Group, Thanthawi Jauhari as the LKPP E-Catalog Working Group 2015. The testimonies of the witnesses can be used as evidence to be held accountable for state financial losses in the procurement of agricultural machinery at the Indonesian Ministry of Agriculture (Detikcom. 2020).

This case explains that procurement personnel, both procurement officials, $\mathrm{CMO}$, and electoral working groups in the government procurement of goods and services are closely related to the procurement process. Besides, previously in the Presidential Regulation 16/2018, there was a Work Product Recipient Committee (PPHP) which also always dealt with the government procurement of goods and services as regulated in Article 1 Number 15 of Presidential Regulation 16/2018, but currently, this provision is removed in the Presidential Regulation 12/2021. In my opinion, the elimination of PPHP in Presidential Regulation 12/2021 is considered as a form of efficiency in the government procurement of goods and services, besides that in some cases, PPHP is always checked if irregularities are found because the results of the inspection affect the quality of goods and services provided. Not to mention if PPHP is appointed from a team that is less relevant and does not have competency standards for the goods and services it inspects. Therefore, in the current Presidential Regulation 12/2021, Article 74A paragraph (6) states the requirements for a certificate of competence for procurement actors have been regulated (Presidential Regulation 12/2021, Article 74A paragraph 6).

Although currently procurement has been carried out electronically, the process of procuring goods and services cannot be separated from human interference. This is often the potential for corruption in the E-Procurement system through E-Catalogs. In fact, the conventional mode of corruption still exists, but with a few modifications. At the planning stage, procurement personnel will make specifications that refer to a certain product, the specifications made orders from certain parties that are made in great detail (Yakobus Tefa. 2013). 
Before that, there was usually a conspiracy / conspiracy with the providers of goods and services, not to mention that there was a reward as a form of bribery and gratuity which led to a meeting of the minds of the two sides. After the procurement specification requirements are determined, the person will select the product from the provider. Providers are indeed difficult to pay the price because at the beginning they have negotiated with LKPP, but they usually play (mark-up) on delivery costs. Procurement personnel can also get cashback if the procurement is large, this is known as a kickback in the procurement of government goods and services.

Whereas if there is an examination from either the law enforcement apparatus or an audit from the Audit Board of Indonesia (BPK) or the Finance and Development Supervisory Agency (BPKP), they will argue if their choice is by the needs in budget planning. They think that the act does not violate the rules, because sharing the margin is the right of the provider. These fraudulent practices are common in E-Tendering, so it is not impossible that in E-Purcashing, these dirty practices can often occur. They forgot about the conspiracy at the beginning of the procurement, indirectly enriching themselves with public money. State losses must exist, because in this case the state is forced to buy goods that have been regulated by the mechanism so that this situation has implications for unfair business competition and is even categorized as acts of corruption, collusion, and nepotism.

Conspiracy, mark-up, kickback, bribery, gratuities or other corruption, collusion and nepotism are categorized as prohibited acts in the government procurement of government goods and services. The provisions governing sanctions in Article 78 to Article 82 in the Presidential Regulation 12/2021 were also amended, but not related to the substance of the amount, but only the compilation of phrases and sequences, as well as the addition of administrative sanctions in the form of Black List Sanctions for providers who do not sign catalog contracts.(Presidential Regulation 12/2021, Article 81 paragraph (4) letter b). Procurement actors, both procurement personnel such as Budget User (PA), Budget User Authority (KPA), Procurement Committees, CMO (PPK) and Goods and Services Providers can be given administrative sanctions as in the Presidential Regulation 12/2021 jo. Presidential Regulation 16/2018 and criminal sanctions as stipulated in Law Number 5 of 1999 concerning Competition Law and Law Number 31 of 1999 jo. Law Number 20 of 2001 concerning Corruption Law. Regarding the occurrence of unfair business competition, this falls under the authority of the Indonesian Competition Commission (KPPU), while criminal acts of corruption can fall under the authority of the Police, the Attorney General's Office and the Corruption Eradication Commission (KPK) (Ferdinand, A. et al. 2020).

The government's policy in updating the rules for government procurement of goods and services in the Presidential Regulation 12/2021 which is aimed at fixing the electronic procurement system can open up great opportunities for MSEs and Cooperatives to be involved in the procurement of government needs. In terms of procurement actors, Presidential Regulation 12/2021 also adds mandatory requirements for competency certificates for procurement of basic / level-1 goods and services for procurement managers and other personnel as stipulated in Article 74 A in the Presidential Regulation 12/2021. This compulsory competency certificate policy can raise the service standards for the procurement of goods and services with qualified human resources and can reduce fake procurement actors who are not by their fields which makes the procurement process not optimal. Even so, the policy still needs to be supported by the professionalism of human resources and personnel involved in procurement. They must comply with ethics, principles, and integrity pacts towards the procurement of government goods and services in their respective $\mathrm{M} / \mathrm{I} / \mathrm{RG}$. Then, as explained in the previous chapter, there is a need for additional qualification requirements on technical goods and service providers as well as the financial capacity of providers from MSEs and Cooperatives which are regulated in the National Procurement Board (LKPP) implementing regulations. This limitation is not to break the spirit but to protect the goodwill of the government and to create an optimal and efficient procurement process. Besides, supervision that is continuously intensified by LKPP and law enforcers can also prevent and eradicate unfair business competition and even the potential for corruption, collusion, and nepotism in the procurement of government goods and services including for MSEs and Cooperatives.

\section{Conclusion}

Presidential Regulation 12/2021 has changed several provisions for the government procurement of goods and services in the Presidential Regulation 16/2018, especially for MSEs and Cooperatives, where medium-sized enterprises activities have been removed and replaced with cooperative businesses. The M/I/RG obligation to allocate at least $40 \%$ of the expenditure budget for MSEs and Cooperatives and the budget ceiling limit for MSEs and Cooperatives has been increased 6 (six) times from IDR 2,5 billion IDR 15 billion. This policy change is the government's effort to encourage the small business sector such as MSEs and Cooperatives to 
actively participate in the government procurement of goods and services and is expected to open up as many job opportunities as possible to encourage economic transformation in Indonesia. Presidential Regulation 12/2021 has emphasized that the government procurement of goods and services for MSEs and Cooperatives can be done using the E-Purchasing method through E-Catalogs and Online Stores. Besides, there is an obligation for a competency certificate for the procurement of basic / level-1 goods and services for procurement managers and other personnel who can raise service standards for the procurement of goods and services. The potential for corruption in the procurement of goods and services electronically cannot be eliminated, either in the form of conspiracies, mark-ups, kickbacks and bribes, and gratuities. However, it is hoped that the new policy in the Presidential Regulation 12/2021 can increase the transparency and integrity of procurement personnel, as well as produces quality and efficient products for MSEs and Cooperatives. Hopefully, the National Procurement Board (LKPP) can make new implementing regulations that are adjusted to changes in government procurement policies in Presidential Regulation 12/2021, especially for MSEs and Cooperatives. The National Procurement Board (LKPP) can amend PerLKPP 9/2018 by adding requirements for technical qualifications of goods and services as well as financial capacity for providers. This is intended so that the implementation of procurement is not only concerned with low prices but also can produce quality and efficient goods and services. This limitation is also expected so as not to reduce the enthusiasm of new business actors but still be able to maintain the good intentions of the government to provide more space for MSEs and Cooperatives and to minimize the emergence of various kinds of irregularities, one of which is corruption, collusion, and nepotism.

\section{Acknowledgments}

This research arises because it cannot be separated from the existence of the Center for Anti-Corruption and Human Rights Community Studies (Puskamsikham) which has always been a forum for the academic community to develop their knowledge and knowledge in exploring corruption law, especially in Lampung Province in collaboration with the Corruption Eradication Commission (KPK). We also extend our greetings to the Faculty of Law and the University of Lampung, and grateful for the criticisms and inputs provided by colleagues in the Journal of Advances in Social Sciences and Policy (JASSP).

\section{Reference}

Adrian Sutedi. (2012). Aspek Hukum Pengadaan Barang dan Jasa dan Berbagai Permasalahannya: Vol. Ed. 2, Cet. 1 (Ade Hairul Rachman, Ed.). Sinar Grafika. http://library.stikptik.ac.id/detail?id=49261\&lokasi=lokal

Azijah Dewi Noor. (2019). ANALISIS DAMPAK PENERAPAN PERATURAN PRESIDEN NOMOR 4 TAHUN 2015 TERHADAP PELAKSANAAN PENGADAAN BARANG/JASA PEMERINTAH DI PEMERINTAHAN DAERAH. Jurnal Ilmu Sosial Dan Ilmu Politik, 3(2), 10-22.

Beridiansyah. (2017). Analisis Yuridis Terhadap Pengadaan Barang Dan Jasa Guna Mencegah Tindak Pidana Korupsi. Integritas, 3(2), 79-104. https://doi.org/https://doi.org/10.32697/integritas.v3i2

BPMI Setpres. (2020, October 9). Presiden: UU Cipta Kerja untuk Reformasi Struktural dan Percepat Transformasi Ekonomi. https:/www.presidenri.go.id/siaran-pers/presiden-uu-cipta-kerja-untukreformasi-struktural-dan-percepat-transformasi-ekonomi/

Business, H. (1983). Purchasing Must Become Supply Management Peter Kraljic. https://abaspro.com.ar/wpcontent/uploads/2019/05/Kraljic.pdf

Detikcom. (2020). Usut Kasus Dugaan Korupsi Alsintan Kementan 2015, Kejagung Periksa 4 Saksi. https://news.detik.com/berita/d-5038031/usut-kasus-dugaan-korupsi-alsintan-kementan-2015kejagung-periksa-4-saksi

Ferdinand, A. K., DM, S., \& Shafira, M. (2020). PENEGAKAN HUKUM DALAM PENGADAAN BARANG DAN JASA PEMERINTAH OLEH KOMISI PENGAWAS PERSAINGAN USAHA (KPPU) DAN KOMISI PEMBERANTASAN KORUPSI (KPK). Cepalo, 4(2), 93. https://doi.org/10.25041/cepalo.v4no2.2006

Haryati, D., Anditya, A., \& Wibowo, R. A. (2011). PELAKSANAAN PENGADAAN BARANG/JASA SECARA ELEKTRONIK (E-PROCUREMENT) PADA PEMERINTAH KOTA YOGYAKARTA *. Mimbar Hukum, 23(2), 237-429.

Henry Campbell Black, M. A. (1968). Black Law Dictionary. West Publishing Co.

Iqbal, M. (2020). PENGARUH PELAKSANAAN E KATALOG DALAM PENGADAAN BARANG/JASA PEMERINTAH TERHADAP UMKM. Jurnal USM Law Review, 3.

Kementerian Keuangan. (2014). WARTA EPROC - Publikasi Layanan E-Procurement Kementerian Keuangan.

Kementerian Koperasi dan UKM. (n.d.). BANGGA UMKM KEMENTERIAN KOPERASI DAN UKM REPUBLIK INDONESIA. 
KPK. (2021). Graph TPK Berdasarkan Jenis Perkara. https://www.kpk.go.id/id/statistik/penindakan/tpkberdasarkan-jenis-perkara

Lestyowati, J. (2018). ANALISIS PERMASALAHAN E-PURCHASING DALAM PENGADAAN BARANG DAN JASA SATUAN KERJA.

Liziad Aditya Soetanto, Kenny Setiobudi Jonathan, \& Paulus Nugraha. (2015). ANALISA KENDALA PELAKSANAAN E-PROCUREMENT DI KOTA SURABAYA. Jurnal Dimensi Pratama Teknik Sipil, 4(2).

LKPP. (2021a). INAPROC - PORTAL PENGADAAN NASIONAL. https://inaproc.id/

LKPP. (2021b). MATRIKS PERUBAHAN PERATURAN PRESIDEN NO 12 TAHUN 2021 TENTANG PERUBAHAN ATAS PERATURAN PRESIDEN NO 16 TAHUN 2018 TENTANG PENGADAAN BARANG/JASA PEMERINTAH.

LKPP. (2021c, February 26). LKPP Mulai Gelar Sosialisasi Peraturan Presiden Nomor 12 Tahun 2021. http://www.lkpp.go.id/v3/\#/read/6018

Makarim, \& Taira S. (2021). The New Regulation on Government Procurement of Goods and Services. https://www.makarim.com/storage/uploads/10561d7c-a70a-47bc-a975-bbff07d47cc1/831297_Mar2021---Issue-2---The-New-Regulation-on-Government-Procurement-of-Goods-and-Services.pdf

Muzakir Haitami, \& Alya Rengganis. (2021). The Dilemma of Good Governance Implementation in Indonesia during the Pandemic of Corona Virus Disease (COVID-19). Journal of Advance in Social Sciences and Policy, 1(1), 55-67. https://doi.org/https://doi.org/10.23960/jassp.v1i1.25

PERATURAN PRESIDEN REPUBLIK INDONESIA NOMOR 12 TAHUN 2021 TENTANG PERUBAHAN PERATURAN PRESIDEN NOMOR 16 TAHUN 2018 TENTANG PENGADAAN BARANG/JASA PEMERINTAH. (2021).

Pusat Bahasa Departemen Pendidikan Nasional. (2008). KAMUS BAHASA INDONESIA.

Rendra Alfonso Sitorus, Syafruddin Kalo, Mahmul Siregar, \& M. Ekaputra. (2019). TINJAUAN YURIDIS PERTANGGUNGJAWABAN PIDANA KORUPSI PENGADAAN ALAT KESEHATAN RSUD SIDIKALANG: STUDI PUTUSAN PENGADILAN NEGERI MEDAN NO. 61/PID.SUSTPK/2016/PN-MDN. USU LAW JOURNAL, 7(7).

Sabrina Dyah Nayabarani. (2017). MEMBANGUN TRANSPARANSI PENGADAAN BARANG DAN JASA MELALUI PENINGKATAN PERAN ICT DALAM MEREDUKSI KORUPSI. Jurnal Hukum Dan Pembangunan , 47(4), 477-496. https://doi.org/http://dx.doi.org/10.21143/jhp.vol47.no4.1586

UNDANG-UNDANG REPUBLIK INDONESIA NOMOR 11 TAHUN 2020 TENTANG CIPTA KERJA. (2020).

UNDANG-UNDANG REPUBLIK INDONESIA NOMOR 20 TAHUN 2008 TENTANG USAHA MIKRO, KECIL DAN MENENGAH. (2008).

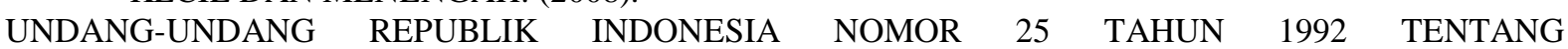
PENGKOPERASIAN. (n.d.).

Yakobus Tefa. (2013). KORUPSI DALAM PENGADAAN BARANG/JASA SECARA ELEKTRONIK CORRUPTION IN THE ELECTRONIC GOVERNMENT PROCUREMENT. JURNAL NESTOR MAGISTER HUKUM, 2(2). 